\title{
ВНУТРІШНЬООСОБИСТІСНИЙ КОНФЛІКТ ЯК КРИЗА ГАРМОНІЗАЦЇ̈ ОСОБИСТОСТІ
}

УдК: 159.964 .21

\section{Тимофієва Марина Пилипівна}

Кандидат психологічних наук, доиент кафедри психології та філософії Вищцого державного навчального закладу України, «Буковинський державний медичний університет», м. Чернівиі (Україна)

\section{Любіна Любов Анатоліївна}

Кандидат психологічних наук, викладач кафедри психології та філософії Вищчого державного навчального закладу України, «Буковинський державний медичний університет», м. Чернівиі (Украӥна)

\begin{abstract}
Анотація. У статті представлено результати теоретичного аналізу категорій «внутрішньоособистісний конфлікт» та «гармонія особистості». Здійснено спробу розкрити взаємозв'язок механізму внутрішньоособистісного конфлікту $i$ психосоматичних розладів. Охарактеризовані захисні механізми та їх роль у формуванні психологічного здоров'я. Представлено стислий огляд наукових досліджень щзодо поняття внутрішньої гармонії як адаптивного механізму психічного здоров'я. Розкриті стратегії поведінки та природа виникнення неврозу за К. Хорні. За теорією неврозу розуміння природи внутрішньоособистісного конфлікту є необхідним для психологічного здоров'я, зокрема илях до гармонії особистості K. Хорні бачила в русі до самореалізаџї. Встановлено, щуо для вирішення внутрішньоособистісних конфліктів передбачається застосування основних принцииів $і$ способів, які з урахуванням індивідуальної специфіки можуть використовуватись у різних ситуаціях.
\end{abstract}

Ключові слова: внутрішньоособистісний конфлікт, криза, гармонія особистості, невроз, психосоматичні розлади.

Постановка проблеми. На сучасному етапі розвитку суспільства, в період криз, людство, більш ніж коли-небудь, починає шукати способи виходу зі стану нестійкості, за- мислюється над своїм психологічним станом і здоров'ям. Тому одним із способів подолання внутрішніх і міжособистісних конфліктів стає гармонізація стану людини. Внутрішня гармо- 
нія є механізмом нашої психіки, яка забезпечує психічне та психологічне здоров'я на всіх рівнях.

Внутрішньоособистісний конфлікт (в подальшому ВОК) - один із самих складних психологічних конфліктів, який панує у внутрішньому світі людини. Різноманітні переживання особистістю своєї неоднозначності, нездатності вирішити ту чи іншу життєву проблему, складності й суперечності свого внутрішнього світу, усвідомлення мінливості власних бажань, прагнень і домагань, часто неможливості їх реалізації, коливання, сумніви, боротьба мотивів - усе це є полем ВОК.

ВОК можна позначити як гостре негативне переживання, яке викликано боротьбою структур внутрішнього світу, що затягнулась та відображає зв'язки із соціальним середовищем, які $є$ антагоністичними та затримують прийняття рішення [1].

Аналіз останніх досліджень. Соціально успішна людина $є$ психологічно зрілою особистістю, творчо сприймає життя, здатна створити або «оживити» зовнішній і внутрішній світ завдяки спонтанній активності власних психічних сил, має перспективний і об'єктивний погляд на реальність, що передбачає звільнення від внутрішніх деструкцій. Особистість, яка здатна до розкриття власного потенціалу, є психологічно здоровою. Сутність гармонійного розвитку людини найбільш повно розкривається у вивченні досвіду психологічно благополучних осіб, які мають здатність відчувати щастя, задоволення від процесу творчої самореалізації, розвитку власних ресурсів і потенціалу.

Платон говорив про те, що здоров'я, як i краса, визначається домірністю, вимагає «згоди протилежностей» і виражається в розмірному співвідношенні душевного і тілесного.

Теоретико-методологічний аналіз для розуміння психологічної сутності та природи внутрішньоособистісних конфліктів у вітчизняній психології поклали дослідження
К. Абульханової-Славської,
Л. Божович,

Ф. Василюка,

Г. Костюка,

О. Лєонтьєва,

С. Мадді,

В. М'ясищева,

В. Мерліна,

О. Ранка,

С. Рубінштейна,

В. Століна,

Т.Титаренко, А. Файзуллаєва та ін.

В гуманістичній і екзистенційній психології конфлікт виникає, насамперед, між значущими цінностями і потребами, на яких грунтується сенс життя людини, між Яконцепцією людини i iï досвідом [5], між спрямуванням до самоактуалізації і реальним результатом [4].

У теорії поля конфліктують «сили різної величини», які впливають на особистість, у когнітивній психології - особистісні конструкти, знання, образи [6].

Аналіз проблеми показує, що досліджуються переважно соціальні, міжособистісні та психофізіологічні чинники внутрішньоособистісного конфлікту (в подальшому ВОК). Проте, фактично відсутні грунтовні дослідження, 
які б вивчали вплив ВОК на складові психологічної гармонії особистості. Поряд із цим, проблема ВОК як кризи гармонізації особистості у вітчизняній психології вивчена недостатньо.

Метою даної публікації $є$ розкриття поняття гармонійної особистості та дослідження іiї психологічних підструктур, а також взаємозв'язку і впливу ВОК на відчуття психологічної гармонії особистості.

Виклад основного матеріалу дослідження. Гармонійна особистість - це психологічно врівноважена особистість, злагоджена внутрішньо і зовнішньо, у неї характерний прояв цілісності психічних властивостей $\mathrm{i}$ процесів. Психологічна гармонія виробляється у процесі виховання особи й участі ії у життедіяльності. Поняття гармонії можна розглядати в різних аспектах. Основні з них: розмірне існування зовнішнього і внутрішнього буття особистості; тілесного, психічного і духовного буття; існування в різних середовищах - природному, предметному, соціальному. Ще один аспект гармонії особистості - узгодженість розвитку й функціонування основних сфер особистості.

Із Середніх віків у західній цивілізації домінують цінності розвитку пізнавальної (когнітивної) сфери особистості. Однак велика кількість знань не робить автоматично людину ні гармонічнішою, ні благополучнішою.

Е. Кант розумів гармонію, перш за все, як узгодженість між розумом і чуттєвістю. В його підході до розуміння гармонії можемо вбачати не тільки філософські, але й психологічні аспекти, адже і за сучасними уявленнями інтелект і почуття є важливими складовими особистості.

Згідно з концепцією В. Франкла, головною рушійною силою життя кожної людини $€$ пошук ним сенсу життя і боротьба за нього. Відсутність сенсу життя породжує у людини стан, який він називає екзистенціальним вакуумом, або почуттям безцільності і порожнечі. Саме екзистенційний вакуум і стає причиною внутрішньоособистісного конфлікту, який надалі призводить до «ноогенних неврозів» (від гр. noos --- сенс), порушується гармонія особистості в значеннях смислу і цінностей людського існування, які складають основу поведінки особистості.

Шлімакова I. I. дослідила та обгрунтувала поняття внутрішньої гармонії як адаптивного механізму психічного здоров'я. Науково виправданим, на іï думку, є рівневий підхід до визначення психічного здоров'я, запропонований Б.С. Братусем:

перший - вищий «особистісно-смисловий рівень», який визначається якістю смислових відношень людини, загальним сенсом іiі життя, ставленням до себе (даний рівень регулює нижче розташовані, підпорядковані рівні);

другий - «індивідуально-психологічний рівень», оцінка якого залежить від спроможності людини будувати адекватні спосо- 
би реалізації смислових спрямувань; третій - «психофізіологічний рівень» визначається особливостями внутрішньої, мозкової, нейрофізіологічної організації актів психічної діяльності.

Важливо прагнути не повної, а оптимальної досконалості, причому для кожного вона $є$ індивідуальною. Особистісна досконалість, багато в чому, залежить від внутрішньої збалансованості людини. Внутрішня гармонія є механізмом нашої психіки, яка забезпечує функціонування психічного здоров'я на всіх його рівнях [8].

К. Хорні стверджує, що дуже часто в житті наші інтереси, переконання стикаються з інтересами й переконаннями людей, що нас оточують. А оскільки такі сутички між нами й оточуючими носять повсякденний характер, то внутрішні конфлікти складають невід’ємну частину людського життя.

Людина має виключне право вибирати, але іноді це право стає важкою ношею. Ми можемо вибирати між протилежними бажаннями. Наприклад, з часом нам подобається виконувати роботу не за фахом, або ми прагнемо залишитися наодинці, але потрібно приділити час друзями тощо. Також можливий конфлікт між бажаннями й обов'язками: ми можемо хотіти побути з дорогою нам людиною в той час, коли хто-небудь знаходиться в біді, потребує нашої допомоги. Нарешті, можливий конфлікт між двома множинами цінностей. Наприклад, коли ми переконані, що необхідно погодитися на ризиковану роботу у воєнний час, і переконані також, що зобов'язані захистити свою родину.

Звідки ж росте коріння внутрішнього конфлікту? 3 перших секунд існування людина починає відчувати ворожість світу. Тривога викликає прагнення до безпеки. Протилежною потребою людини є прагнення до задоволення своїх бажань. Ці тенденції часто суперечать одна одній і тоді виникає внутрішній конфлікт, який людина сама прагне придушити, виробляючи певні стратегії поведінки.

К. Хорні виділила наступні стратегії поведінки:

1) Зниження значущості одного з конфліктуючих потягів і піднесення значення йому протилежного.

2) «Рух від людей» - спроба вирішення конфлікту за рахунок емоційної дистанції між «Я» та іншими.

3) «Рух від самого себе». Характеризується тим, що для особистості справжнє цілісне «Я» перестає бути реальним. На місці реального «Я» внутрішньо конфліктуюча особистість створює ідеалізований образ самого себе, в якому конфліктуючі сторони настільки видозмінюються, що більше не здаються такими, а виглядають різними сторонами «багатої» особистості. Тепер потреба досконало виглядає як спроба досягти відповідності зі своїм ідеалізованим образом. Бажання бути предметом захоплення можна розглядати як потребу невротичної особис- 
тості мати зовнішнє підтвердження того, що вона дійсно відповідає своєму ідеалізованому образу. Ідеалізований образ породжує новий внутрішній розкол особистості і тому вимагає організації нових захисних механізмів.

4) Екстерналізація. Якщо ідеалізований образ означає крок у бік від дійсного «Я», то екстерналізація представляє ще більш радикальне розходження. Вона породжує нові конфлікти або значно загострює вихідний конфлікт - між «Я» і зовнішнім світом.

За дослідженнями К. Хорні, менш важливими виявляються такі стратегії, як деспотична справедливість, де головною функцією є придушення всіх внутрішніх сумнівів; жорсткий самоконтроль, який за допомогою неймовірної сили волі стримує «разриваючуся» особистість від повного розпаду; і цинізм, який, зневажливо ставлячись до всіх цінностей, виключає всі конфлікти, породжені несумісністю ідеалів.

3. Фройд, К. Хорні стверджують, що суперечливі умови життя, ВОК породжують неврози. Невроз виникає на фоні психологічної травми, якщо можна так висловитися, середнього ступеня важкості. Невроз - психічний розлад особистості, причиною якого $\epsilon$ стресові ситуації, конфлікти тривалого характеру, які супроводжуються психологічними мікротравмами. Невроз - це неконструктивне рішення протиріччя між особисті- стю і дійсністю на несвідомому рівні.

Хоча основна увага в теорії неврозів спрямована на вирішення проблем, що існують у даний момент, постулат «всі проблеми родом 3 дитинства» залишається в силі. В результаті несприятливих умов в дитинстві у дитини розвивається не почуття «ми», а гостре відчуття незахищеності і похмурі передчуття, для визначення яких К. Хорні використовує термін базальна тривога. Щоб зменшити цю тривогу дитина може вибрати один із трьох напрямків: йти до людей, проти людей або геть від них.

Отже, опираючись на теорію неврозу за К. Хорні, стверджуємо, що динамічний центр утворює базисний конфлікт між атитюдами «рух до людей», «рух проти» і «рух від людей». Із-за свого страху бути розколотим на частини, з одного боку, і необхідністю функціонувати в якості єдиної особистості - 3 іншого, невротик робить відчайдушні спроби вирішити цей конфлікт. Поки він здатний створювати якусь подібність штучної рівноваги, постійно виникають нові конфлікти i постійно потрібні все більш нові засоби для їх нейтралізації. Кожен крок у цій боротьбі за єдність особистості робить невротика більш ворожим, безпорадним, нерішучим, відчуженим від самого себе й інших, а результатом стає те, що перешкоди, відповідальні за конфлікт, стають ще більш непереборними, а їх реальне усунення - все більш недосяжним. Нарешті, втрачається всяка надія і відновлю- 
ються деструктивні поведінкові реакції, які в свою чергу породжують нові внутрішньоособистісні конфлікти.

Оскільки конфлікти часто стосуються переконань, віри чи моральних цінностей, їх визнання передбачає, що ми розвинули свою власну систему цінностей. Запозичені переконання не є частиною нашого «Я», вони володіють достатньою силою, щоб викликати конфлікти або служити провідним критерієм при прийнятті рішень. Такі переконання, якщо на них чиниться вплив, легко замінюються іншими. Якщо ми просто запозичили вирощені в нашому оточенні цінності, то внутрішні конфлікти не виникають [7, с.120-250].

Отже, за теорією неврозу розуміння природи ВОК є досить важливим для психологічного здоров'я, зокрема шлях до гармонії особистості К. Хорні бачила в русі до самореалізації. Кінцева мета - знайти себе і зайняти своє місце у світі [там само].

Німецький психолог Е. Фромм підкреслює двоїсту природу людини. 3 одного боку, особистість прагне до незалежності, а 3 іншого - хоче уникнути цієї незалежності, оскільки вона приведе до відчуження. Конкуренція, боротьба за владу, престиж і статус протиставляють людину людині і суспільству в цілому. Найбільш різко цей процес самовідчуження i руйнування особистості в нашій країні проявився у зв'язку з розвитком ринкових відносин. Прагнення до багатства і влади за будьяку ціну нерідко змушує людей поступатися своїми принципами. Людина перестає поважати думку інших людей, намагається заглушити голос власного сумління, і в результаті втрачає себе, відчужується від своєї сутності. Внутрішній конфлікт нерідко виникає між прагненням мати якомога більше і можливістю при цьому поважати себе за свої людські якості.

Під час теоретико-

методологічного дослідження ВОК як кризи гармонії особистості неможливо не розкрити взаємозв'язок механізму ВОК і психосоматичних розладів. Провідною патогенетичною ланкою $є$ виникнення гострого або хронічного психологічного конфлікту, який особистість не здатна залагодити. В. Мейєр і Е. Чессер вказують на інтенсивний або тривалий вплив конфліктної ситуації як на обов'язкову умову психосоматичних захворювань.

Усі варіанти психологічних конфліктів поділяються на дві групи: неможливість досягнути мети - викликає тривогу; позбавлення задоволення потреб - зумовлює фрустрацію. При цьому можливі такі патопсихологічні механізми розвитку конфліктних ситуацій: підвищені особистий рівень домагань та самооцінка; неспівпадіння потреб та особистої системи цінностей - боротьба між «обов'язком та бажанням»; неспівпадіння об'єктивних особистих можливостей та аутовимог.

На перелічені вище внутрішньоособистісні конфлікти індивід реагує компенсаторнопристосувальними механізмами психологічно- 
го захисту, серед яких - психологічне ігнорування, заперечення існування конфлікту, раціоналізація, інтелектуалізація перетворення важливості конфлікту, перемикання мети, зміна діяльності, «відхід у роботу», хобі. Але найпоказовішим $\epsilon$ такий компенсаторнопристосувальний механізм психологічного захисту, як дезадаптація - формування патологічних симптомів як механізму, що звільняє від відповідальності - «відхід у роботу». А. Менегетті переконаний, що «... психосоматичне захворювання означає, що причина хвороби або соматичного симптому, яким би він не був, бере свій початок виключно у сфері психічного. Мова не йде про те, що психічна причинність лише супроводжує соматичний наслідок. Психічному початку, який втілюється у сомі, у тілесності, віддається абсолютний примат у процесі виникнення хвороби». Період між внутрішнім конфліктом і його соматичним перетворенням може варіювати і складає від кількох днів до кількох років. Час перехідного періоду від психічного до соматики, як стверджує онтопсихологічний напрямок, зазвичай визначається або ситуацією, що є причиною зриву, або травматичним середовищем, що підсилює травму, а також способами реакції, які стали типовими для суб'єкта. Тяжкість того, що відбувається в оточуючій реальності, визначається не іiі об'єктивними причинами, а тим, як реальність сприймається суб'єктом. Один із онтопсихологічних принципів психосоматики проголо- шує, що психічна діяльність - це енергетична складова частина великого цілого з відкритим проектом. Кожна людина при народженні опиняється у певному контексті, потенційні можливості якого практично безмежні. Але в реальності, як зазначає А. Менегетті, життєва, інтелектуальна і творча енергія будь-якої людини використовується лише на 10, максимум на $30 \%$.

Деструктивними наслідками вважають ті, що призводять до затяжних психічних розладів, які сприяють розвитку невротичних реакцій та стають основою для виникнення кризових ситуацій. У ракурсі деструктивних наслідків ВОК розглядають ситуації коли:

затяжний внутрішній конфлікт знижує ефективність діяльності;

постійна рефлексія та сумніви послаблюють особистісні якості, спотворюють піi творчий потенціал, зменшують активність, занурюють у постійне роздвоєння; довготривалі внутрішні конфлікти уповільнюють розвиток особистості. На думку Л. Божовича, така людина виглядає невпевненою, не стримана у своїй поведінці, не вміє досягати свідомо поставлених цілей, а отже, вона буде психологічно незрілою;

часті внутрішньоособистісні конфлікти можуть призвести до того, що людина втратить впевненість у власних силах, у неї сформується стійкий комплекс неповноцінності та втрата сенсу життя; 
порушуються відносини на роботі, в сім'ї, виникають міжособистісні конфлікти; особистість стає агресивною, тривожною, у неї частіше з'являються депресії та нервові розлади [2].

Вирішення внутрішньоособистісних конфліктів передбачає застосування основних принципів і способів, які з урахуванням індивідуальної специфіки можуть використовуватись у різних ситуаціях. До них належать: адекватна оцінка ситуації і прагнення виявити ті суперечності, які послугували причиною конфлікту і викликали відчуття тривоги, страху або гніву;

усвідомлення екзистенціального сенсу конфлікту, аналіз міри його важливості, оцінка місця і ролі з погляду наслідку;

локалізація причини конфлікту, виявлення його суті;

аналіз причин внутрішньоособистісного конфлікту;

використання фізичних вправ, творчих занять;

відчуття напружених м'язів 3 подальшим проведення індивідуального розслабляючого сеансу;

зміна умов i/або стилю своєї роботи, якщо внутрішньоособистісний конфлікт виникає постійно через несприятливі умови діяльності;

вивчення можливості зниження рівня домагань, якщо здібності та можливості не відповідають прагненням та інтересам; відпрацювання уміння прощати не лише інших, але й себе;

підвищити рівень впевненості; вміти виділити пріоритетні мотиви й потреби i зосередитись на їх виконання в першу чергу.

\section{Висновки та перспективи подальших} досліджень.

Внутрішньоособистісний конфлікт, природно притаманний внутрішній структурі особистості -- нормальне явище. Особистості властиві внутрішні суперечності й боротьба між різними прагненнями. Зазвичай ця боротьба проходить у межах норми і не порушує гармонійності особистості. Адже гармонійна особистість зовсім не $\epsilon$ особистість, що не знає ніякої внутрішньої боротьби. Але іноді ця боротьба стає пріоритетною, що визначає поведінку людини і весь спосіб життя.

Вирішення внутрішнього конфлікту це процес відновлення узгодженості внутрішнього світу особистості, встановлення єдності психіки, зниження гостроти суперечностей життєвих відносин. Психологічно гармонійна особистість вміє керувати своїми емоціями, поважає себе та інших. Усвідомлена участь у конфлікті, хоча це і може приносити страждання, може бути безцінною гідністю. Чим більше особистість бере участь у вирішенні своїх внутрішніх конфліктів, тим більшу внутрішню свободу й силу набуває.

Подальшого дослідження потребує дослідження розуміння та прояву внутрішньоо- 
собистісного конфлікту у студентів-медиків та подальшою розробкою тренінгових вправ.

\section{Перелік використаних джерел:}

1. Аниупов А. Я., Шипилов А.И. Конфликтология: учебник для ВУЗов. - М.: ЮНИТИ, 1999. - 551 с.

2. Дугельна Т. Причини виникнення внутрішньоособистісних конфліктів. URL: http://nss.in.ua/index.php? part=4107 (дата звернення: 11.09.2016).

3. Малейчук Г.И. Обоснование психологической модели психического здоровья. URL: http://www.b17.ru/ article/761 (дата звернення: 30.03.2017).

4. Маслоу А. Мотивация и личность. - СПб.: Евразия, 1999. $-478 \mathrm{c}$.

5. Роджерс К. Взгляд на психотерапию. Становление человека. - М.: Прогресс «Универс», 1994. - 480 с.

6. Фестингер Л. Теория когнитивного диссонанса. СПб.: Речь, 2000. -318 с.

7. Хорни К. Наши внутренние конфликты. - М.: Апрель -Пресс, Изд-во ЭКСМО-Пресс, 2000. - С. 120 - 250.

8. Шлімакова I. I. Внутрішня гармонія як адаптивний механізм психічного здоров'я. URL: http:// www.nbuv.gov.ua/old_jrn/Soc_Gum/Vchdpu/

psy/2012_103_2/Shlimak.pdf_ (дата звернення: 11.09.2016).

\section{References (Transliteration):}

1. Antsupov A.Ya., Shipilov A.I. Konfliktologiya: uchebnik dlya VUZov. - M.: YuNITI, 1999. - 551 s.

2. Dugelna $T$. Prichini viniknennya vnutrIshnoosobistIsnih konflIktIv. URL: http://nss.in.ua/index.php?part=4107 (data zvernennya: 11.09.2016).

3. Maleychuk G. I. Obosnovanie psihologicheskoy modeli psihicheskogo zdorovya. URL: http://www.b17.ru/ article/761 (data zvernennya: 30.03.2017).

4. Maslou A. Motivatsiya i lichnost. - SPb.: Evraziya, 1999.
$-478 \mathrm{~s}$.

5. Rodzhers $K$. Vzglyad na psihoterapiyu. Stanovlenie cheloveka. - M.: Progress «Univers», 1994. - 480 s.

6. Festinger L. Teoriya kognitivnogo dissonansa. - SPb.: Rech, 2000. $-318 \mathrm{~s}$.

7. Horni K. Nashi vnutrennie konfliktyi. - M.: Aprel-Press, Izd-vo EKSMO-Press, 2000. - P. 120 - 250.

8. ShlImakova I.I. VnutrIshnya garmonIya yak adaptivniy mehanIzm psihIchnogo zdorov'ya. URL: http:// www.nbuv.gov.ua/old_jrn/Soc_Gum/Vchdpu/ psy/2012_103_2/Shlimak.pdf_ (data zvernennya: 11.09.2016).

\section{Tymofiieva Marina}

Ph.D. in Psychology,associate professor of psychology and philosophy, Higher State Educational Establishment of Ukraine "Bukovinian State Medical University», Chernovtsy (Ukraine)

\section{Liubina Liubov}

Ph.D. in Psychology, lecturer in psychology and philosophy, Higher State Educational Establishment of Ukraine «Bukovinian State Medical University», Chernovtsy (Ukraine)

\section{INTRAPERSONAL CONFLICT AS HARMONIZATION CRISIS OF IDENTITY}

\section{ABSTRACT}

The results of the theoretical analysis of the categories of «intrapersonal conflict» and «harmony of the individual» are presented in the article. It is attempted to reveal the relationship of mechanism of IPC and psychosomatic disorders. The protective mechanisms and their role in shaping of psychological health are characterized. A brief review of researches according to the concept of inner harmony as an adaptive mechanism for mental health is presented. The 
behavior strategies and nature of neurosis by $\mathrm{K}$. Horney are disclosed. According to the theory of neurosis the understanding of the nature of intrapersonal conflicts is essential for mental health, in particular K. Horney saw the way to the harmony of personality by the movement to self-realization. It is found that to solve intrapersonal conflicts it is expected to apply the basic principles and methods, which, can be used in different situations given according to the individual specifics.

Solving interpersonal conflicts involves the application of basic principles and methods that are considering individual specifics can be used in different situations. These include: adequate assessment of the situation and the desire to identify the contradictions that have provided the cause of the conflict and caused anxiety, fear or anger; awareness of the existential meaning of the conflict, analysis of importance degree, evaluation of place and role in terms of consequences; localization of conflict causes, identify its substance; analysis of the causes of intrapersonal conflicts; the use of physical exercise, creative classes; feeling of muscle tense and then relaxing session of an individual; changing conditions and / or style of work if intrapersonal conflict occurs persistent because of unfavorable conditions of work; exploration the possibility of reducing the level of claims if skills and capabilities do not meet the aspirations and interests; testing the ability to forgive not only others, but oneself; increase the level of confidence; be able to identify priority needs and motives and focus to perform them firstly.

Intrapersonal conflict, naturally is peculiar to internal structure of personality. Contradictions and struggle between different aspirations are inherit to personalities. Usually this struggle is within the rules and not violate the harmony of the individual. Harmonious personality is not a person that knows no internal struggle. But sometimes this fight becomes a priority that determines human behavior and the entire way of life.

Keywords: intrapersonal conflict, crisis, harmonization of personality, neurosis, psychosomatic disorders.

\section{Тимофеева Марина Филипповна}

Кандидат психологических наук, доиент кафедры психологии и философии Выстего государственного образовательного учреждения Украины, «Буковинский государственный медицинский университет», г. Черновuьы, (Украина)

\section{Любина Любовь Анатолиевна}

Кандидат психологических наук, преподаватель кафедры психологии и философии Высшего государственного образовательного учреждения Украины «Буковинский государственный медицинский университет», г. Черновиы (Украина)

\section{ВНУТРИЛИЧНОСТНЫЙ КОНФЛИКТ КАК КРИЗИС ГАРМОНИЗАЦИИ ЛИЧНОСТИ}

Аннотация. В статье представлены результаты теоретического анализа категорий «внутриличностный конфликт» и «гармония личности». Попытка выявить механизм взаи- 
мосвязи внутриличностного конфликта и психосоматических расстройств. Охарактеризованы защитные механизмы и их роль в формировании психологического здоровья. Представлен краткий обзор исследований концепции внутренней гармонии как адаптивного механизма психического здоровья. Раскрыты стратегии поведения и природа возникновения невроза за К. Хорни. Понимание природы внутриличностного конфликта в теории невроза необходимо для психологического здоровья, в частности путь к гармонии личности К. Хорни видела в движении к самореализации. Установлено, что для решения внутриличностных конфликтов предусматривается применение основных принципов и способов, которые с учетом индивидуальной специфики могут использоваться в различных ситуациях.

Во время исследования были раскрыты и описаны деструктивные последствия которые приводят к затяжным психическим расстройствам и способствуют развитию невротических реакций, становятся основой для возникновения кризисных ситуаций. В ракурсе деструктивных последствий внутришньоособистсного конфликта рассматривают ситуации, когда: затяжной внутренний конфликт снижает эффективность деятельности; постоянная рефлексия и сомнения ослабляют личностные качества, искажают ее творческий потенциал, уменьшают активность, погружают в постоянное раздвоение; долговременные внутренние конфликты замедляют развитие личности.

Ключевые слова: внутриличностный конфликт, кризис, гармонизация личности, невроз, психосоматические расстройства.
Дата отримання статті: 27.02.2017

Дата рекомендації до друку: 02.03.2017 